Workers and Employers 
OTHER BOOKS BY J. T. WARD

The Factory Movement (1962)

Sir James Graham (1967)

The Factory System (2 vols, 1970)

Popular Movements (Problems in Focus series, 1970)

Land and Industry (co-edited with T. G. Wilson, I97 I)

Chartism (1973)

The Age of Change (1975)

Scottish Themes (co-edited with J. Butt, 1976)

OTHER BOOKS BY W. HAMISH FRASER

Trade Unions and Society: The. Struggle for Acceptance, 1850-1880 (1973) 


\title{
Workers and Employers
}

Documents on Trade Unions and Industrial Relations in Britaın Since the Eighteenth Century

\author{
Edited by \\ J. T. WARD \\ and \\ W. HAMISH FRASER
}


Introduction, selection and editorial matter (C) J. T. Ward and W. Hamish Fraser 1980

All rights reserved. No part of this publication may be reproduced or transmitted, in any form or by any means, without permission.

First published Ig8o by

THE MACMILLAN PRESS LTD

London and Basingstoke

Associated companies in Delhi Dublin

Hong Kong Johannesburg Lagos Melbourne

New York Singapore and Tokyo

British Library Cataloguing in Publication Data

Workers and employers.

I. Industrial relations-Great Britain-

History-Sources

I. Ward, John Towers II. Fraser, William

Hamish

331'.094 I HD8390

ISBN 978-0-333-15413-7 ISBN 978-1-349-16277-2 (eBook)

DOI $10.1007 / 978-1-349-16277-2$

This book is sold subject to the standard conditions of the Net Book Agreement.

The paperback edition of this book is sold subject to the condition that it shall not, by way of trade or otherwise, be lent, resold, hired out, or

otherwise circulated without the publisher's prior consent, in any form of binding or cover other than that in which it is published and without

a similar condition including this condition being imposed on the subsequent purchaser. 


\section{Contents}

Acknowledgements vii

Abbreviations $\quad$ ix

Introduction $\quad \mathrm{xi}$

Table of contents xiii

I Roots and Origins I

2 The Turbulent Years, 1825-42 23

3 Towards Acceptance, $1843-67 \quad 58$

4 Investigation and Vindication, $1867-75 \quad 93$

5 The Unskilled 108

6 The Growth of Collective Bargaining $\quad$ I 35

7 The Militant Years 160

8 The First World War and After $\quad$ I89

9 The Years of Crises $\quad 222$

Io Consolidation Despite Economic Difficulties 249

I I The Second World War and After 272

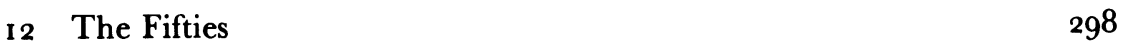

I3 The Sixties 3 3 3

I4 The Search for a Solution 347

$\begin{array}{ll}\text { Index } & 366\end{array}$ 
To

KAy and Helen 


\section{Acknowledgements}

The authors and publishers wish to thank the following who have kindly given permission for the use of copyright material:

Amalgamated Union of Engineering Workers for extracts from their Union Journals, I966 and 1974; Birmingham City Libraries for the extract from the letter from Wall to Rennie from the Boulton and Watt Collection; British Institute of Management for extracts from The Making of Scientific Management, II ( I949), by L. F. Urwick and E. F. L. Brech; The British Library of Political and Economic Science for the extract from the Minutes of the Conference of Almagamated Trades; Cambridge University Press Ltd for extracts from Wages and Income in U.K. Since 1860 by A. L. Rowley (1937) and Industrial Relations in a British Car Factory by G. Clack (University of Cambridge, Dept of Applied Economics, Occasional Paper, No. 9); The Controller of H.M. Stationery Office for the letter from George Salmond to D. Cleghorn and the letter from John Greig to the Lord Advocate; The Council of the Scottish History Society for the extract from the Minutes of the Edinburgh Trades Council 1859-I873 (I968) ed. Ian MacDougall; Aidan Crawley and Times Newspapers Ltd for an extract from Signpost to Success ( 1957) reprinted in the Sunday Times (6-27 January 1957); The Daily Telegraph Ltd for an extract from an article in the Daily Telegraph (27 May 1952); Faber and Faber Ltd for an extract from Sir James Sexton, Agitaır. The Life of the Dockers' M. P. by Sir James Sexton; Fabian Society for an extract from Industrial Relations: Sweden Shows the Way by J. Cooper, Fabian Research Series 235; The Financial Times Ltd for an extract from an article in the Financial Times 27 November 1974); Furniture, Timber and Allied Trades Union for extracts from the Trades Union Congress i940 Award 'Relations Between Unions' Statement; General and Municipal Workers' Union for extracts from NUGMW Journal 1955, Evidence to Royal Commission on Trade Unions 1966 and Why an Incomes Policy?; Guardian Newspapers Ltd for an extract from Trades Union Congress 1965 by P. Jenkins; William Heinemann Ltd for an extract from Winston S. Churchill II Companion Part II ( I 969), by R. S. Churchill; Lawrence \& Wishart Ltd for extracts from Revolt on the Clyde by W. Gallacher and Serving My Time and Trade Unionists- 
viii

What Next? by H. Pollitt; Liverpool City Libraries and Liverpool Trades Council for the extract from the letter from Robert Applegarth to Charles Williams; National Union of Mineworkers for extracts from their published reports of 1936, 1943, 1944 and 1945; National Union of Public Employees for extracts from Five Years Review 1939; Public Employees Fournal March/April 195I; The Challenge of New Unionism, 1963 and Public Employee, October 1970; Policy Studies Institute for an extract from The Structure and Organisation of British Trade Unions; Sheffield University Library for extracts from The Mundella-Leader Correspondence in the Mundella Papers; Society of Graphical and Allied Trades for an extract from the General Rules; Times Newspapers Ltd for an extract from a Law Report in The Times (22 January 1964), and a news report on the Electrical Trades Union from the Sunday Times (1 0 May 1953); Trades Union Congress for extracts from TUC Statements and Reports; Transport and General Workers Union for extracts from TGWU The Union, Its Work and Problems (1939).

Every effort has been made to trace all the copyright holders but if any have been inadvertently overlooked the publishers will be pleased to make the necessary arrangement at the first opportunity. 


\section{Abbreviations}

AEU

ASCJ

ASE

ASLEF

ASRS

ASCJ

ASW

AUEFW

AUEW

CBI

DATA

ETU

FBI

GRWU

ICI

IRLR

IRSF

ISKTC

LTC

MFGB

NAFTA

NALGO

NAPSS

NASDS

NATSOPA

NEDC

NIRC

NUGMW

NUJ

NUM

NUPE

NUR
Amalgamated Engineering Union

Amalgamated Society of Carpenters and Joiners

Amalgamated Society of Engineers

Associated Society of Locomotive Engineers and Firemen

Amalgamated Society of Railway Servants

Amalgamated Society of Carpenters and Joiners

Amalgamated Society of Woodworkers

Amalgamated Union of Engineering and Foundry Workers

Amalgamated Union of Engineering Workers

Confederation of British Industries

Draughtsmen and Allied Trades' Association

Electrical Trades' Union

Federation of British Industries

General Railway Workers' Union

Imperial Chemical Industries

Industrial Relations Law Reports

Inland Revenue Staff Federation

Iron, Steel and Kindred Trades' Confederation

London Trades Council

Miners' Federation of Great Britain

National Amalgamated Furnishing Trades' Association

National Association of Local Government Officers

National Association for the Promotion of Social Science

National Amalgamated Stevedores and Dockers' Society

National Society of Operative Printers and Assistants

National Economic Development Council

National Industrial Relations Court

National Union of General and Municipal Workers

National Union of Journalists

National Union of Mineworkers

National Union of Public Employees

National Union of Railwaymen 
Parl. Debs

$P P$

RC

RCA

SC

TA

TUC TGWU

WEA
Hansard Parliamentary Debates

British Parliamentary Papers

Royal Commission

Railway Clerks' Association

Select Committee

Typographical Association

Trades Union Congress

Transport and General Workers' Union

Workers' Educational Association 


\section{Introduction}

The study of labour history has developed rapidly in recent years. Learned societies debate the subject; learned journals are devoted to it; University and other classes attempt to study it. A plethora of studies, ranging from the superb to the trivial and from the academically argued to the polemically contrived, has been published. A serious and important branch of Clio's craft has come of age.

However, despite the development of wide interest in the history of labour and industrial relations, teachers and students alike have long complained about the dearth of accessible documentary tools for their trade. Certainly, some collections of material have appeared from time to time. But we believe that a comprehensive collection may now be of value.

In selecting extracts from a wide range of published and other material we have observed some self-imposed rules. From the start, we determined that we would not present an annotated general history of British industrial relations; instead, editorial comment has been kept to a minimum, to allow the documents to 'speak for themselves'. Secondly, we have intentionally avoided broadening our theme to comprehend what some writers have called 'the working-class movement'. We have generally eschewed politics, except where it inevitably impinged on our central theme.

Of course, any selection rests upon personal choice. In preparing this book, we have reluctantly (and sometimes even sadly) decided to delete or abbreviate long-cherished and carefully transcribed documents. Our aim has been to produce a fair and balanced collection of material which may be useful as a source book to everyone interested in a theme which fascinates us.

While the editorial decisions inevitably remain our responsibility, we have to thank very many people, too numerous to mention individually by name, who have given us generous help over the years. To some of our colleagues in the University of Strathclyde, to many officials and members of trade unions and trades councils, to many managers, industrialists, teachers and lecturers, to many other friends and not least to our students we owe sincere thanks for helpful advice and suggestions which have helped to contour our approach to the subject. We hope that they may understand our inability to acknowledge the kindness of each and every one of them. 
We are deeply indebted to Mr Derick Mirfin of Macmillan for his longsustained encouragement and tolerant forbearance as our labours were elongated, and to Sarah Mahaffy who finally saw the book to press. We also owe our deep gratitude to our typists, Miss Catherine Summerhill and Mrs Elizabeth Thrippleton, who patiently deciphered an often difficult manuscript. Finally, we are grateful for the understanding patience of our wives and children during the long gestation of this book.

J. T. W.

W. H. F. 


\section{Table of Contents}

\section{Roots and Origins}

(I) H. T. Riley, Memorials of London and London Life in the XIIIth, XIVth and XVth Centuries ( I 868) [Rich. II, AD I396. Letter-book H, fo. ccix]

(2) An Act Touching Divers Orders for Artificers, Labourers, Servants in Husbandry and Apprentices, 1563, 5 Eliz. c. iv, Statutes of the Realm, IV

(3) An Act Empowering Justices to Fix Minimum Rates of Payment, i6o3, I Jas I, c. 6, Statutes of the Realm, IV

(4) C. A. Malcolm, The Minutes of the Justices of the Peace for Lanarkshire I707-I723 (Edinburgh: Scottish History Society, 193I)

(5) F. W. Galton, Select Documents Illustrating the History of Trade Unionism: The Tailoring Trade (1896), 'The Case of the Master Taylors Residing within the Cities of London and Westminster ... Humbly offer'd to the Consideration of Parliament (1 720$)^{\prime}$

(6) Works of the late Celebrated B. Franklin: Consisting of His Life, by Himself, and Essays (Edinburgh, 1808)

(7) J. C., DD, The Weaver's Pocket Book: or Weaving Spiritualized (Dundee; I 766)

(8) Galton, Select Documents . . . 'The Case of the Journeymen Taylors and Journeymen Staymakers, Residing within the Cities of London and Westminster, and Weekly Bills of Mortality', presented to the House of Commons, 28 Jan $175^{2}$

(9) James Watt to John Rennie, Birmingham, 2 July I 786 , Boulton and Watt Collection, Birmingham Reference Library

(10) W. A. Appleton, Trade Unions. Their Past, Present and Future (1925), Rules of the Friendly Associated Cotton Spinners

( I I) Combination Act, I80o, 39 and 40 Geo. III, c. Io6

(12) 'Articles of Agreement. Made, concluded and agreed upon by the Amicable and Brotherly Society of Journeymen Millwrights, held 
at the Red Lion, Clements Lane [crossed out in original] Swan in Fish St. Hill, City of London, this twelfth day of October, I80 I, in pursuance of Act of Parliament, passed in the thirty second year of his present Majesty, intituled "An Act for the Encouragement and Relief of Friendly Societies",

(13) Commons fournals (17 July I8o6): Report on Calico Printers' Petition

(14) Commons Journals (26 Feb. 1807): Petition of Journeymen Cotton Weavers

(15) W. Taylor, An Answer to Mr. Carlile's Sketches of Paisley (Paisley, I 809)

(16) Society of (London) Journeymen Brushmakers, Articles (1806)

( 7 ) Keighley Royal Benefit Society, Rules and Regulations (Leeds, I8 I 2)

(18) R. M. Lancaster, Leeds Typographical Society . . Centenary, I810I9Io: A Souvenir (Leeds, I910), Rules and Regulations of the Leeds Typographical Society ( 1815 )

(19) Annual Register for I8II ( I 81 2)

(20) Dr Robert Taylor, Letters on the Subject of the Lancashire Riots in the Year I8I2 (Bolton, I 8 I 3 )

(2 I) Scots Magazine, Lxxv (April I8I3)

(22) Lord Meadowbank's judgement on the Glasgow Weavers, Glasgow Herald (i9 March I8I3)

(23) Parl. Debs, ist ser., xxv (6 April I8I3)

(24) The Gorgon (3 Oct. I818)

(25) 'Philanthropic Hercules', The Gorgon (23 Jan. I8I9)

(26) Home Office Papers, 42/181: Philanthropic Society

(27) Address to the Labouring Classes in the Manufacturing Districts (Halifax, 1823)

(28) Parl. Debs, and ser., x (1 2 Feb. 1824)

(29) Parl. Debs, 2nd ser., xII (29 March 1825)

\section{The Turbulent Years, I825-42}

(I) The Glasgow Mechanics' Magazine ( 1824 ): 'Address on the Repeal of the Combination Laws to the Mechanics of Scotland'

(2) Thomas Hodgskin, Labour Defended against the Claims of Capital (1825)

(3) SC on Combination Laws, $P P$ I 825 IV, appendix no. I 3

(4) The Combination of Workmen Act, I 8254 Geo. IV, c. 34

(5) Rules of the Mechanics' Friendly Institution, as Agreed upon by the Deputies from the Different Branches, Convened at Leeds, Aug. 16th, 1824 (Bolton, 1824)

(6) Steam Engine Makers' Society, Annual Report, I9I9 
(7) 'Abstract of the Evidence of Combinations of Workmen taken before a Select Committee of the House of Commons in 1838', NAPSS, Trades' Societies and Strikes ( 1860 )

(8) Articles of the Association of Operative Cotton-Spinners of Glasgow and Neighbourhood (1833)

(9) Home Office Papers, 40/27: Resolutions of the delegates at the Isle of Man Conference of Operative Cotton Spinners

( 10) Herald to the Trades' Advocate, no. 6 (30 Oct. I83o)

(I I) Penny Papers for the People (26 March 1831)

(12) The Crisis, III, no. 2 I (18 Jan. 1834)

(13) Herald to the Trades' Advocate, no. 34 (14 May I83 I): 'Fundamental Laws of the Glasgow and West of Scotland Association for the Protection of Labour'

(14) The Crisis, I, no. 4I (I 5 Dec. I832): William Pare, Birmingham, to Robert Owen

( 15$)$ To the United Working Builders of Great Britain and Ireland ( 2 Sept. 1833)

(16) The Crisis, III, no. 16 (14 Dec. 1833)

(1 7) The Crisis, III, no. 2 I (I 8 Jan. 1834)

(18) E. C. Tufnell, The Character, Objects and Effects of Trades Unions (1834)

(19) The Crisis, III, no. 27 (I March I834)

(20) The Tradesman (12 April 1834): Address of Robert Owen

(2 I) The Crisis, IV, no. 7 (24 May 1834): 'A Memorial from the Grand National Consolidated Trades' Union of Great Britain and Ireland, to the Producers and Non-producers of Wealth and Knowledge'

(22) 'To the Operative Cordwainers' (letter from William Hoare), The Pioneer, no. 43 (28 June I 834)

(23) The Book of the Martyrs of Tolpuddle (1934): Leaflet circulated in Dorset (Feb. 1834)

(24) George Loveless, Victims of Whiggery ( 1837 )

(25) Morning Chronicle (2 April 1834)

(26) The Spectator (5 April 1834)

(27) Catholic Magazine (March I834)

(28) The Crisis, IV, no. I I (2 I June I 834)

(29) Richard Oastler, Serious Address to the Millowners, Manufacturers, and Cloth-Dressers of Leeds (Huddersfield, I834)

(30) Richard Oastler, A Few Words to the Friends and Enemies of Trades' Unions (Huddersfield, i 834)

(31) New Moral World (3 Oct. 1835)

(32) SC on Combinations of Workmen, First Report, PP, I837-8, viII: Evidence of John Doherty

(33) W. Cleland, Former and Present State of Glasgow (Glasgow Statistical Society, 1836 ) 
(34) George Salmond, Procurator Fiscal of Glasgow, to D. Cleghorn, 29 Aug. I837 [MS letter in Crown Agents' Papers, Scottish Record Office]

(35) E. C. Tufnell, The Character, Objects and Effects of Trades Unions ( 1834 )

(36) John Greig, Edinburgh, to Lord Advocate ( 6 March I838) [MS letter in Crown Agents' Papers, Scottish Record Office]

(37) A Voice from Prison, The Address of the Glasgow Cotton Spinners to Hugh Alexander, Chairman of Glasgow Committee of Trades, etc. (Edinburgh, 1838)

(38) The Monthly Liberator, III (9 June I838): 'Cotton Spinners' Case.

Truth v. Law

(39) SC on Combinations of Workmen, $P P$ I 837-8 virr: Evidence of Sir Archibald Alison, Sheriff of Lanarkshire

(40) Observations on Power-Looms (Glasgow, I826)

(4I) G. S. Bull, The Cause of Industry (Bradford, I 835)

(42) Report of Committee on Hand-Loom Weavers, PP I 835 XIII

(43) Paisley United Weavers, Charleston District Meeting Minutes, Dec. 1834-Aug. 1835 [Paisley Museum]

(44) Francis Place, 'Handloom Weavers and Factory Workers' in Pamphlets for the People, no. 16 ( 1835 )

(45) The New Liberator (6 Jan. 1838)

(46) The New Liberator (6 Jan. I838): Speech of Joseph Rayner Stephens at Glasgow on the trial of the cotton spinners

(47) William Benbow, Grand National Holiday and Congress of the Productive Classes ( 1832 )

(48) The West London Boot and Shoemakers' Charter Association to the Trades of London, The Charter (28 April 1842)

(49) Midland Mining Commission, First Report, PP I 843 xIII: Evidence of Earl of Dartmouth, acting as Lord Lieutenant of the County of Stafford

(50) Manchester Guardian (24 Aug. I842): placard issued, 'To the PowerLoom Weavers of Manchester and Salford and the Surrounding Districts'

(51) The Life of Thomas Cooper (1872)

(52) Manchester Guardian (24 Aug. 1842): Meeting of Manchester tailors to receive report of William Duffy on proceedings of the trades delegates

3. Towards Acceptance, $1843-67$

(1) The Jubilee Volume of the London Society of Compositors ( 1898 ): Address of General Trade Society of Compositors of London, I May I 833 
(2) The Compositor's Chronicle (I Feb. I 84 I): Tenth Annual Report of the Northern Typographical Union, Nov. 1839 to Dec. 1840

(3) Rules and Regulations to be Observed by the Members of the Journeymen Steam Engine Makers and Millwrights Friendly Society ( 1 843)

(4) SC on Masters and Operatives (Equitable Councils of Conciliation), Report, PP 1856 , xIII: Evidence of Thomas Winter

(5) Rules of the ASE ( 185 I), Preface

(6) Address of the Executive Council of the Amalgamated Society of Engineers to Their Fellow Workmen throughout the United Kingdom and British Colonies ( 1855 )

(7) NAPSS, Trades' Societies and Strikes (1860): Declaration of the Executive Council of the Amalgamated Society of Engineers, 2 February $185^{2}$

(8) Ibid., 'Representation of the Case of the Executive Committee of the Central Association of Employers of Operative Engineers, \&c.'

(9) 'Employers' Strike. Notice. To the Public and Working Classes of Keithley [sic]' ( $185^{2}$ ) [Keighley Reference Library]

(10) The Times (12 Jan. 1852).

(I I) W. A. Jevons, 'Account of the Weavers' Strike at Padiham in I 859', in NAPSS, Trades' Societies and Strikes (1860)

(12) The Typographical Circular (I Jan. I 855)

(13) Report of SC on Masters and Operatives (Equitable Councils of Conciliation), PP I 856 xirr: Evidence of J. C. Proudfoot

(14) Henry Broadhurst MP, The Story of His Life from a Stonemason's Bench to the Treasury Bench, Told by Himself ( I gor)

(15) Edinburgh Review, cx (1859), 'Secret Organization of Trades'

(16) NAPSS, Trades' Societies and Strikes (1 860)

(1 7) Notes to the People (8 Oct. 1853)

(18) The People's Paper ( 15 Oct. I 853)

(19) Ernest Jones, 'Balance Sheet of Chartism', Chartist Circular (23 Oct. 1858)

(20) London Operative Bricklayers' Society, Report and Balance Sheet of the Dispute Relating to the Attempt to Introduce the System of Hiring and Paying by the Hour (186I)

(2 I) A Short History of London Trades Council, by a Delegate: Circular convening a conference of delegates from trade societies to be held in Shaftesbury Hall, Aldersgate, I 8 May 1860

(22) Constitution of the LTC (186o)

(23) Bee-Hive (26 March I 864): Fourth Report of the LTC

(24) RC on Trades Unions and Employers' Associations, First Report, $P P$ I 867 xxxIr: Evidence of Robert Applegarth, General Secretary of the Amalgamated Society of Carpenters

(25) RC on Trades Unions etc., First Report, PP I 867 xxxir: Evidence of William Allan, General Secretary of the ASE 
(26) Ibid.: Evidence of Robert Applegarth 75

(27) ASCJ, Annual Report (1867) 76

(28) T. J. Dunning, Trades Unions and Strikes (1860) 76

(29) RC on Trades Unions etc., Tenth Report, PP ı 867-8 xxxix: Evidence of T. J. Wilkinson, General Secretary of the Flint Glassmakers' Society

(30) RC on Trades Unions etc., Seventh Report, PP I 867-8 xxxix: Evidence of Alexander McDonald, President of the National Association of Coal, Iron and Limestone Miners

(3i) ASCJ, Monthly Report (May I865)

(32) Bee-Hive (9 May I 863): Report of Paper by Alexander Campbell 79

(33) Reynolds' Weekly Newspaper (Io Nov. I 86I) 80

(34) Miner and Workman's Advocate ( 16 Sept. I 865)

80

(35) Bee-Hive (25 Aug. 1866): Circular from the Manchester and Salford Trades Council

81

(36) RC on Trades Unions etc., Fifth Report, PP I 867-8 xxxıx: Paper submitted by John Jones, secretary of the Iron Manufacturers' Association and of the Ironmasters' Association

82

(37) Capital and Labour, By a Member of the Manchester Chamber of Commerce ( 1867$)$ : Trade Unions

(38) G. H. Smith, Outlines of Political Economy (1866)

(39) Potteries Examiner and Workman's Advocate (22 June 1844)

(40) The Operative (12 April I85I)

(4I) T. J. Dunning, Trades' Unions and Strikes: Their Philosophy and Intention ( 1860 )

(42) Scottish History Society, The Minutes of Edinburgh Trades Council 1859-73, ed. Ian MacDougal (Edinburgh, I968), pp. 107-8

(43) Rules for the Government of the United Kingdom Alliance of Organised Trades as adopted at the Conference held in Manchester, January Ist. I867 and three following days (Sheffield, i 867)

(44) RC on Trade Unions etc., First Report, PP 1867 xxxII

(45) Ibid.: Evidence of Samuel Crookes $\quad 88$

(46) Hornby v. Close ( 1867 ) LR 2QB I53 89

(47) LTC, Annual Report and Balance Sheet, 1872-73 89

(48) Report of the Trades Conference held at St. Martin's Hall, London, on March 5th, 6th, 7th and 8th, I867: Report from the Committee of the Working Men's Association

(49) MS. Minutes of the Conference of Amalgamated Trades, 8 March I867 [British Library of Political and Economic Science]

\section{Investigation and Vindication, $1867-75$}

(I) J. M. Ludlow and Lloyd Jones, Progress of the Working Class, 1832I867 ( I 867) 
(2) The Life of Thomas Cooper, written by himself (1872)

(3) RC on Trades Unions etc., Eleventh and Final Report, PP I868-9 xxxı: Majority Report

(4) Ibid.: Minority Report

(5) 'Proposed Congress of Trades Councils and other Federations of Trades Societies' [TUC Library; quoted in A. E. Musson, Trade Union and Social History (1974)]

(6) Robert Applegarth to Charles Williams, General Secretary of the National Association of Operative Plasterers, I3 March 1868 [Picton Library, Liverpool]

(7) The Boiler Makers' and Iron Ship Builders' Society, Monthly Report (April r 869)

(8) Frederic Harrison, 'The Trades Union Bill', Fortnightly Review (I July i 869)

(9) The Trade Union Act, I87 I, 34 and 35 Vic., c. 3 I

(10) The Criminal Law Amendment Act, I871, 34 and 35 Vic., c. 32

(I I) Regina v. Bunn [1872], I 2 Cox CC 316

(1 2) LTC, To Trade Societies on Repeal of the Criminal Law Amendment Act Demonstration, Whit-Monday, June 2nd 1873

(13) Nine Hours' Movement in the North of England, E. Allen, The North-East Engineers' Strikes of I87I (Newcastle, I97 I), p. I I 4

(14) Capital and Labour (3 I Dec. 1873), The National Federation of Associated Employers of Labour

(15) A. J. Mundella to R. Leader, Sheffield, 2 I March I874, [Sheffield University Library]

(16) Conspiracy and Protection of Property Act, I 875, 38 and 39 Vic., c. 86

(1 7 ) Employers and Workmen Act, 1875, 38 and 39 Vic., c. 90

(18) Trade Union Act Amendment Act, I876, 39 and 4o Vic., c. 22

\section{The Unskilled}

(I) Bee-Hive (2 July I 864): Editorial comment

(2) Bee-Hive (25 Feb. 1865)

108

(3) Bee-Hive (2 March 1872 )

108

(4) Stamford Mercury (3 May 1872), 'Labourers' Association Conference at Grantham'

(5) Joseph Arch, The Story of His Life (1 898)

(6) Labourers' Union Chronicle (2 I Aug. 1875)

(7) The Labourer (30 June I 877)

(8) Bee-Hive (9 Dec. I87I): Objects of the ASRS

(9) TUC 7th Annual Report (1875)

(1 ) RC on Labour, PP I $89^{2}$ xxxv, Group B, r: Evidence of J. Havelock Wilson, General Secretary of the National Amalgamated Sailors' and Firemen's Union of Great Britain and Ireland 
(I I) Ben Tillett, Memories and Reflections (I93 I) I I 3

(12) The Link (2 I July I888) I I 4

(13) Minutes of the LTC, 5 Oct. I 888 I I 5

(14) Tillett, Memories and Reflections 1 I 5

(15) RC on Labour, PP I892 xxxv, Group B, I: Evidence of John Polhill, free labourer

( 16) SC on the Sweating System, $P P$ I 890, xvir $\quad$ I 6

(17) H. A. Mess, Casual Labour ai the Docks (19i6) I 6

(i 8) F. Harrison, 'The New Trade Unionism' Nineteenth Century, CLII (Nov. I889) $\quad$ I 18

(19) TUC, 23rd Annual Report (189o); Report of Parliamentary Committee

(20) Liverpool Trades Council, Annual Report I890-I

(2 I) George Howell; Trade Unionism New and Old ( I89I)

(22) Dundee Year Book, I89I (Dundee, I 892):

(a) Evidence of the Rev. H. Williamson, President of the Dundee Mill and Factory Operatives' Union, to the RC on Labour

(b) Evidence of James Reid of the Dundee Trades Council

(23) Tom Mann and Ben Tillett, The 'New' Trades Unionism (June I 89o)

(24) Tom Mann, Tom Mann's Memoirs (1923), quoting The'New' Trades Unionism-A Reply to Mr. George Shipton

(25) Harry Quelch, Trade Unionism, Co-operation and Social Democracy (Sept. I892)

I 18

I 19

(26) Alliance Cabinet Makers' Monthly Report, no. I53 (March I 888): 'Questions on Eight-Hour Working Day from the Parliamentary Committee of TUC'

(27) North British Daily Mail (2 Feb. I888)

(28) TUC, 23rd Annual Report (189o)

(29) Manningham Strike Fund, To the Trades' Unionists of the United Kingdom (Bradford Trades and Labour Council, I89I)

(30) E. A. Pratt, Trade Unionism and British Industry (1904)

(3I) Will Thorne, in NUGMW, Souvenir History (1929)

(32) RC on Labour, PP I 892 xxxv, Group B, I, appendix viII, 'Circular Giving the General Scope of the Operations of the Shipping Federation, 20 October I 89o'

(33) Ibid.: Evidence of E. A. Earnsby, free labourer

(34) William Collison, The Apostle of Free Labour (I9I3)

(35) RC on Labour, PP $1892 \times x x v$, Group B: Evidence of Harry Quelch, representing steamship workers of South Side Labour Protection League

(36) J. Sexton (General Secretary of the National Union of Dock Labourers), Sir James Sexton, Agitator. The Life of the Dockers' M. P. (1936)

37) Minutes of the Parliamentary Committee of TUC, Adjourned 
Meeting of Parliamentary Committee, Io Oct. I894 $13^{2}$

(38) Glasgow United Trades Council, Annual Report I895-6 132

(39) J. Lyons E Sons v. Wilkins [1896], I Ch 8I I 133

(40) Taff Vale Railway Co. v. ASRS [1901], AC 426

(4I) Quinn v. Leathem [190 I], AC 495

I 34

\section{The Growth of Collective Bargaining}

(I) RC on Trades Unions etc., Tenth Report, PP I867-8 xxxix: Evidence of A. J. Mundella, Nottingham hosiery manufacturer

(2) The Ironworkers' Journal ( I May I 876): Paper by B. Samuelson MP on 'The Board of Arbitration and Conciliation for the North of England Manufactured Iron Trade', read to the British Iron Trade Association

(3) The Reformer (3 I Oct. I 868)

(4) Thomas Brassey, Lectures on the Labour Question (1878)

(5) ASE, 25th Annual Report (1875); First report from John Burnett as General Secretary

(6) John Kane, Foreword to Amalgamated Ironworkers' Association, Rules (Darlington, 1870)

(7) A. J. Mundella to R. Leader, Sheffield, 24 Feb. 1876

(8) J. R. Raynes, Coal and Its Conflicts (1928): A South Wales slidingscale agreement, i I Dec. I 875

(9) Ironworkers' Journal (I Feb. 1877)

(10) ASE, Abstract Report of Proceedings of Executive Council (1878-9)

(1 I) Manifesto of the Lancashire Weavers (June 1878), in S. and B. Webb, History of Trade Unionism ( 1894 )

(12) Edinburgh Trades Council, Annual Report, I879-80

(13) RC on Depression of Trade and Industry, Second Report, PP 1886 xxII, appendix D, pt 2; Evidence of the Edinburgh Trades Council

(14) George Howell, 'Trades Unions Apprentices, and Technical Education', Contemporary Review, xxx (1877)

(15) Extract from Ironfounders' Society, Report (Feb. 1 885) [in E. Belfort Bax 'Address to Trades' Unions', issued by the Council of the Socialist League, The Socialist Platform, no. I (1885)]

(16) RC on Labour, PP I893-4 xxxII, Group A, vol. III: Evidence of J. Swift, General Secretary of the Steam Engine Makers' Society

(1 7) Ibid., Précis of the evidence of R. Knight, General Secretary of the United Society of Boilermakers and Iron Shipbuilders

( 18$)$ RCion Labour, PP I 892 xxxvi, pt I, Group B, vol. Ir: Evidence of J. Keir Hardie

(19) RC on Labour, PP I893-4, xxxiII, Group A, vol. III, appendix XLIII: 'Arbitration Proceedings on the Question of the 
Apportionment of Work to be done by the Shipwrights and Joiners in the Shipbuilding and Repairing Yards of the River Tyne. 28 October I889. Umpire's Award. R. Burt, Umpire'

(20) Rules of the United Society of Boilermakers and Iron Shipbuilders (I901): Rule 43.- Members Acting Contrary to Trade Interests

(2 I) RC on Labour, Final Report, PP I 894 xxxv: Majority Report

(22) Ibid.: Minority Report signed by William Abraham, Michael Austin, James Mawdsley and Tom Mann

(23) Ibid.: Final Report, Observations by Chairman and seven members

(24) W. M. Wiggins (President of the Federation of Master Cotton Spinners' Associations), 'Survey of Industrial Relations in the Cotton Industry of Great Britain', in F. E. Gannett and B. F. Catherwood, Industrial and Labour Relations in Great Britain (1939)

(25) Terms of Settlement of the Boot and Shoe Trade Dispute, I 895, in A. Fox, A History of the National Union of Boot and Shoe Operatives (Oxford, 1958)

(26) Minutes of Evidence Taken Before the Industrial Council in Connection with Their Enquiry into Industrial Agreements, Cmd 6953 (1913), appendix XXIII

(27) Ibid.: 'The Engineering Employers' Federation'

(28) W. A. Appleton, Trade Unions. Their Past, Present and Future (1925)

(29) Scottish National Federation of House and Ship Painters, Dundee branch, Payment Card, I895-6: 'Objects'

(30) Amalgamated Association of Card and Blowing Room Operatives, First Annual Report, in Alfred Roberts, After Fifty Years (Ashton, 1936)

(31) The Seamen's Chronicle (24 Oct. I896)

(32) LTC, Government Contracts! Fair Wages and Sub-Contracting ( I89 I)

\section{The Militant Years}

(1) A. L. Bowley, Wages and Income in the United Kingdom since I860 (Cambridge, 1937), Index of money wages and of the cost of living, I880-19I4 (1914= I00)

I6o

(2) Conciliation Act, I896, 59 and 6o, Vic., c. 30

I6 I

(3) RC on Trade Disputes and Trade Combinations, Report, PP I 906 LVI

I6I

(4) Trade Disputes Act, I9o6, 6 Ed. VII, c. 47

163

(5) Bee-Hive ( 5 Sept. I866): notice - 'Union of Railway Servants'

164

(6) G. R. Askwith, Industrial Problems and Disputes (1920): Demands of the 'All Grades Movement'

(7) Ibid.: Conciliation scheme for railways, 1907-'General Principles' 
(8) Post Office circular (13 Feb. 19o6), quoted in Official Recognition: The Story of Postal Trade Unionism (n. d.)

(9) F. E. Gannett and B. F. Catherwood, Industrial and Labour Relations in Great Britain (1939)

(10) Parl. Debs (22 June I 908)

167

(I I) Askwith, Industrial Problems and Disputes: Report of Select Committee on Sweated Trades, I908, under Sir Thomas Whittaker

(12) Memorandum on Labour Exchanges, July 1908, prepared for W. S. Churchill by William Beveridge, in R. S. Churchill, Winston S. Churchill, vol. II, Companion part 2 (I969)

(13) W. V. Osborne, Sane Trade Unionism (n.d.)

(14) ASRS v. Osborne [1910], AC 87

(15) The Trade Union Act, 1913, 2 and 3 Geo. V, c. 30

(16) Askwith, Industrial Problems and Strikes: The Cambrian mining strike

(1 7) Ibid., quoting Philip Snowden, MP

( 18 ) Tom Mann, 'The Transport Workers', The Industrial Syndicalist, I (Aug. I9Io): The London Dockers

(19) H. A. Mess, Casual Labour at the Docks (19i6)

(20) Ibid.

(21) The Transport Worker (I5 Aug. I9I I): Liverpool transport strike

(22) Ben Tillett, Memories and Reflections (I93 I)

(23) L. Urwick and E. F. L. Brech, The Making of Scientific Management, vol II (I 949): 'A Note on the Trade Union Attitude to the Premium Bonus System, 1910'

(24) The Socialist Labour Party: Its Aims and Methods (Edinburgh, r9o8)

(25) Tom Mann, 'Prepare for Action', The Industrial Syndicalist, I, no. I (July igio)

(26) S. and B. Webb, What Syndicalism Means. An Examination of the Origin and Motives of the Movement with an Analysis of its Proposals for the Control of Industry (1912)

(27) South Wales Miners' Reform Committee, The Miners' Next Step (1912)

(28) Tom Mann, Tom Mann's Memoirs (1923): Open Letter to British Soldiers. First printed in the Syndicalist (Jan. 1912)

(29) G. D. H. Cole, The World of Labour (1913)

(30) A. Bellamy JP (President of the NUR), 'Industrial versus Craft Unions', Labour Year Book (1916)

(31) Fred Bramley (National Amalgamated Furnishing Trades Association), 'Craft versus Industrial Unions', The Labour Year Book, (1916)

(32) G. N. Barnes, 'Trade Unionism and Strikes', The Socialist Review, Ix, no. 54 (Aug. I912) 
(33) Robert Smillie, 'The Triple Industrial Alliance', The Labour Year Book (1916)

187

I 88

\section{The First World War and After}

(1) The Labour Year Book (1916): The Treasury Conference

189

(2) W. Gallacher, Revolt on the Clyde (1934): Clyde strike, Feb. I9I5

(3) D. Lloyd George, War Memoirs (1938): Memorandum of I. H. Mitchell of Industrial Commissioners Department, June I 9 I 5

(4) Gallacher, Revolt on the Clyde: Meeting of the Clyde Workers' Committee with Lloyd George, Dec. I9I 5

(5) 'Clyde Munitions Workers. Report of the Rt. Hon. Lord Balfour of Burleigh, K.T., G.C.M.G. and Mr Lynden Macassey, K.C., I9I 5’, $P P$ i9 14-16 xxix

(6) Mines and Quarries: General Report, with Statistics, for 19I8, by the Chief Inspector of Mines, Cmd 490 (I9I9), pt II

(7) Labour Year Book (1916): 'Women and the War'

(8) Labour Year Book (I9I9): The Ministry of Labour

(9) Commission of Inquiry into Industrial Unrest, Report on Wales, PP I 9 I 7-I $8 \mathrm{XV}$

(1о) TUC, Annual Report (I916): Presidential Address by Harry Gosling

( I I) Committee on Relations between Employers and Employed, Final Report, Cmd 9153 (1918)

(12) Labour Research Department, Monthly Circular, III, 6 ( I Dec. 1918)

(13) Report of Provisional Joint Committee, Presented to Meeting of Industrial Conference, Central Hall, Westminster (April 4 1919), Cmd I39

(14) T. Williamson, 'Trade Unionism and Negotiating Machinery in the Gas Industry of Great Britain', in F. E. Gannett and B. F. Catherwood, Industrial and Labour Relations in Great Britain (1939)

(15) L. H. Green (Secretary of the Flour Milling Employers' Federation), 'Labour Problems in the British Flour Milling Industry', in F. E. Gannett and B. F. Catherwood, Industrial and Labour Relations in Great Britain (1939)

(16) Labour Research Department, Monthly Circular, Iv, no. 6 (2 June I9I9)

(17) Ibid., v, no. 6 (i Dec. i919)

(I8) Ibid., III, no. 6 (I Dec. 1918)

(19) Evening News (Glasgow, 3 I Jan. 1919)

(20) NUR Central Strike Committee, Edinburgh District, Strike Bulletin (4 Oct. 1919)

(2 I) Coal Industry Commission Act, 1919. Second Stage. Reports, Cmd 2 1 0 (20 June igig)
I 9 I

I9I

$19^{2}$

192

I 93

I 94

195

I 96

I 98

198

200

200

202

203

204

204

205

205

206

206 
(22) Coal Industry Commission Act 1919. Report by Messrs. R. Smillie, Frank Hodges, and Herbert Smith, Sir Leo Chiozza Money, Messrs. R. H. Tawney and Sidney Webb, Cmd 85 (20 March 1919)

(23) Coal Industry Commission Act 1919. Interim Report by Messrs. R. W. Cooper, 7. T. Forgie, and Evan Williams, Cmd 86 (20 March 1919)

(24) TUC, Annual Report (1919): Resolutions on coal-mining industry

(25) Trade Union Amalgamation Act, I9 7,7 and 8 Geo. V, c. 24

(26) Labour Year Book (1919)

(27) TGWU, The Union, Its Work and Problems (1939)

(28) Labour Research Department, Monthly Circular, vi, no. 6 ( I June 1920)

(29) Labour Year Book (1924)

212

(30) Maurice B. Reckitt and C. E. Bechover, The Meaning of National Guilds (1920 edn)

(31) G. D. H. Cole, Guild Socialism Re-stated (1920)

(32) Labour Research Department, Monthly Circular, vi, no. 2 (I Feb. 1920)

(33) The Times (I5 May 1920)

(34) Labour Research Department, Monthly Circular, viII, no. 2 (I Feb. I92 I)

(35) The Times ( 12 April 192 I)

(36) NUR Central Strike Committee, Edinburgh District, Strike Bulletin (12 April 1921)

\section{The $Y$ ears of Crises}

(I) Labour Research Department, The Workers' Register of Labour and Capital (1923)

(2) Ibid.

(3) FBI, Bulletin (29 Nov. I92 I): Presidential Address by Sir Peter Rylands

(4) FBI, Year Book and Register of British Manufactures (1924)

(5) TGWU, Rules ( I923 edn): Rule 2 -Objects

(6) Trade Unionism in Action. The General Council of the T. U. C: Its Powers, Functions and Work (1925)

(7) TUC, Trade Union Structure and Closer Unity. Interim Report (1944): Resolution at Congress of 1924 in Hull

(8) Daily Herald (19 Jan. I924): 'Threatened Railway Strike. The Companies' Case'

(9) ASLEF, Locomotive Journal (Feb. I924); 'Railway Strike of Locomotivemen'

(1 o) Harry Pollitt, Serving My Time (1940): 'Manifesto of the Provisional International Council of Trade and Industrial Unions to the Organised Workers of Great Britain' (192I) 
(I I) Ibid.: Document issued by the London Committee of the Red International of Labour Unions, 1922

(1 2) Manifesto to the Mineworkers of Fife, Kinross and Clackmannam (March 1925)

(13) F. E. Gannett and B. F. Catherwood, Industrial and Labour Relations in Great Britain (1939): Extract from the evidence of Mr. W. E. Counsell (Trade Board Inspector in Charge of Special Enquiries) given to the Committee appointed to enquire into the working and effects of the Trade Boards Act (The Cave Committee) in Feb. 1922

(14) Industrial Relations Handbook (I944): Agricultural Wages (Regulation) Act, I924, I4 and I5 Geo. V, c. 37

(15) Mining Association, The Mines for the Miners! What Nationalization Really Means (1925)

(16) Committee on Industry and Trade, Survey of Industrial Relations (1926): Negotiating machinery in coal-mining

(1 7) Daily Herald (3 I July i 925)

( 18$)$ Daily Herald (3 I July I925): Declaration of the Special Industrial Committee of the TUC

(19) RC on the Coal Industry, Report, Cmd 2600 (I925), I, 'Cost and Proceeds'

(20) TUC General Council, Mining Dispute National Strike Report of the General Council to the Conference of Executives of Affiliated Unions, 25th June 1926: Exchanges of Letters between General Council of TUC and the Prime Minister, 3 May 1926

(2 I) Daily Mail (4 May 1926)

(22) The Times (5 May 1926)

240

240

(23) Ibid. (6 May 1926)

(24) J. Simon, Three Speeches on the General Strike (1926): Speech by Sir John Simon delivered in the House of Commons, 6 May I 926

Daily Mirror (7 May 1926)

(26) Sunday Pictorial (9 May 1926)

(27) Fred Maddison (former editor of Railway Review, journal of the NUR) in British Gazette (1o May 1926)

(28) British Worker (10 May 1926)

(29) Daily Express (I I May 1926)

(30) British Gazette (12 May 1926)

(31) Daily Chronicle (13 May 1926)

(32) Daily Graphic (13 May 1926)

242

(33) Labour Year Book (1927): 'Proposals for Co-ordinated Action of Trade Unions'

(34) TUC General Council, Mining Dispute National Strike, Report of the General Council to the Conference of Executives of Affiliated Unions, 25 June 1926

(35) Statement of the Miners' Federation of Great Britain on the Occasion of the 
Conference of Trade Union Executive Committees Held to Receive the Report of the General Council of the Trades Union Congress on the Work Entrusted to Them in the General Strike of May, 1926 (1927)

\section{I o. Consolidation Despite Economic Difficulties}

(1) Labour Year Book (1928)

(2) TUC General Council, Industrial Committee, Report to the Executives of Affiliated Unions on the Discussions with the Employers' Group (1928): 'Origin of the Conference'

(3) Sir Ben Turner, About Myself (1930)

(4) The Times (5 July 1928)

(5) A. J. Cook, Mond's Manacles. The Destruction of Trade Unionism (1928): Speech at Conference on Industrial Organisation, 4 July 1928

(6) Ibid.: Speech in St Andrew's Hall, Glasgow, 8 July I928

(7) Labour Year Book (I93 I): Relations with Employers' Organisations

(8) National Union of Scottish Mineworkers, To the Members ... (1928)

$25^{I}$

253

(9) Labour Year Book (I93I)

( о) TUC, Trade Union Structure and Closer Unity. Interim Report (1944): Summary of 1927 report on organisation of unions

(I I) TUC General Council, Pauperising the Unemployed. The T. U. C Case against the Means Test (1932)

(12) Committees on Industry and Trade, Survey of Industrial Relations (1926): Negotiating Machinery in the Cotton Industry

(13) Industrial Relations Handbook (1944): Cotton Manufacturing Industry (Temporary Provisions) Act, I 934, 24 and 25 Geo. V, c. 32

(14) Ibid.: Road and Rail Traffic Act, 1933, 23 and 24 Geo. V, c. 53

(I5) MFGB, Proceedings (1936)

(16) TGWU, The Union, Its Work and Problems (1939): 'List of Amalgamated Unions'

( 7 ) NUPE, Five Years' Review. Address of the General Secretary, Bryn Roberts to the Conference of Organisers held at Anderton's Hotel, Fleet Street, London January 7 th and 8th, 1939

(18) TUC, Trade Union Structure and Closer Unity. Interim Report (1944): Rules of 'Good Trade Union Practice'

(19) Sir A. Pugh, The WEA and the Trade Union Movement (1936)

\section{I. The Second World War and After}

(1) The Trade Unions and the War. Address of the Rt. Hon. Ernest Bevin, Minister of Labour and National Service, to the Trades Union Congress, Cambridge Hall, Southport (1940)

(2) Industrial Relations Handbook (1944): Recommendations of the Joint 
Consultative Committee of the Minister of Labour and National Service, 1940

(3) Ibid.: Conditions of Employment and National Arbitration Orders, $194^{-2}-2$

(4) RC on Trade Unions and Employers' Associations, Report, Cmnd 3623 (1968)

(5) National Union of Furniture Trade Operatives, Statement on a Trades Union Congress 'Relations Between Unions' 1940 Award (1953)

(6) P. Inman, Labour in the Munitions' Industry (1957): Memorandum of Agreement between Engineering and Allied Employers' National Federation and AEU 28 Aug. 1939

(7) Price Stabilisation and Industrial Policy, Cmd 6294 (July I94 I)

(8) TUC, The Trade Unions and Wage Policy in War-Time (1941): Memorandum to the Minister of Labour, July I $94^{1}$

(9) MFGB, Report of Special Conference ... London ...25th and 26th November, 1943: (1943) Speech of Arthur Horner (South Wales)

(10) TUC, Statement on Regulation IAA (3 I May 1944)

( I I) MFGB, The National Reference Tribunal under the Conciliation Scheme in the Coalmining Industry (1944): Evidence of Enoch Edwards

282

(12) Bullcroft NUM, A Final Appeal (1946)-duplicated notice

282

(13) TUC, Interim Report on Post-War Construction (1944)

283

(14) Ibid.: Composite resolution passed unanimously at the Southport TUC, 1943

284

(I5) Ibid.

285

(16) NUM, Annual Conference, 1945. Report of the National Executive Committee (1945)

( 7 ) An Act to Repeal the Trade Disputes and Trade Unions Act, I927, 9 and 10 Geo. VI, c. $5^{2}$

(18) Statement on the Economic Considerations Affecting Relations between Employers and Workers, Cmd 7018 (Jan. 1947)

(19) Statement on Personal Incomes, Costs and Prices, Cmd $73^{2}$ I (Feb. I948)

(20) TUC, Trade Unions and Wages Policy (1950): Report of the TUC General Council to the executives of affiliated unions

(2 I) Ibid.: Speech of Arthur Deakin

(22) Ibid.: Speech of Lincoln Evans

(23) Ibid.: Speech of Jim Mortimer

(24) Ibid.: Speech of Arthur Horner

(25) ISKTC: Man and Metal (April 1944) 292

(26) NUR, Rules (Jan. I942)

(27) Harry Pollitt, Trade Unionists - What Next? (1948) 293

(28) Woodrow Wyatt, The Peril in our Midst (1956) 294

(29) TUC, The Tactics of Disruption-Communist Methods Exposed (1949) 296

(30) Daily Mail (I I July I95 I) 


\section{The Fifties}

(1) NUPE, Public Employees' Journal (March-April I951): Speech of Bryn Roberts, General Secretary, to the Haldane Society

(2) Ibid. (Jan.-Feb. I95I): Paper by Bryn Roberts

(3) Ibid. (March-April I95I): Article by A. W. Fisher

(4) IRSF, Taxes (June I95I)

(5) Daily Telegraph (27 May I952): ETU Conference

(6) Ibid. (1 2 May 1953): ETU Conference, speech by F. Foulkes

(7) TUC, Trades Councils, 1949. Report to the Annual Conference of Trades Councils (1949)

(8) The Spectator (26 Nov. I95I)

(9) Iron and Steel Trades' Confederation, Man and Metal (Feb. 1950): Paper by Lincoln Evans, General Secretary

( I0) Daily Express ( 12 July I 95 I): Report by Trevor Evans on speech by A. Deakin, TGWU conference

(1 I) Daily Telegraph (27 Feb. 1952): National Council of Labour

(12) Daily Telegraph (27 May 1952): F. Foulkes to ETU conference

(13) Daily Mail (ro June 1953)

(14) NUGMW, Journal (June 1955): Article by Tom Williamson, General Secretary

(15) Aidan Crawley, Signpost to Success (1957): repr. from the Sunday Times (6-27 Jan. 1957)

(16) Report of a Court of Inquiry into a Dispute between D. C. Thomson and Company Limited and Certain Workpeople, Members of the National Society of Operative Printers and Assistants, Cmd 8607 (1952)

(17) Yorkshire Post (9 May 1952)

(19) Bonsor v. Musicians' Union, House of Lords [1956] AC I 04

(20) Spring v. NASDS [1956] I WLR $5^{85}$

(2 I) British Transport Commission, Making foint Consultation Work (1956)

(22) Ibid.

(23) ICI, Memorandum on Labour Relations, $5^{\text {th }}$ edn (July 1959)

(24) National Coal Board, Guide to Consultation in the Coalmining Industry, 2nd edn (1963)

(25) Ben Smith, 'The Art of Negotiation', Public Service (June I956) 310

(26) The Workers' Educational Trade Union Committee, 3ist Annual Report (I95I)

(27) Sunday Times ( 1о May 1953)

(28) Special Joint Committee on Machinery of Negotiation for Railway Staff, Report of Railway Pay Committee of Inquiry (2 March 1960) 


\section{The Sixties}

(I) Political and Economic Planning, The Structure and Organisation of British Trade Unions (1963)

(2) General Rules for the Government of the National Union of Printing, Bookbinding and Paper Workers (1960)

(3) NUGMW, This is Your Union (1964)

(4) John Hughes, 'Trade Union Structure and Government', in RC on Trade Unions and Employers' Associations, Research Paper, no. 5 ( 1967 ), pt I

(5) Guild of Insurance Officials, Membership Card (1942 edn)

(6) IRSF, Constitution and Rules (1950 edn)

(7) NUPE, The Challenge of New Unionism (Leicester, 1963)

(8) NUGMW, Evidence to the Royal Commission on Trade Unions and Employers' Associations (1966)

(9) AEU, Journal (Nov. 1966): 'A Joint Statement by the Amalgamated Engineering Union and the Amalgamated Union of Foundry Workers'

(г) TGWU, Shop Stewards Handbook (1964): 'Joint Consultation - Your Responsibilities'

( I I) Garfield Clack, Industrial Relations in a British Car Factory, University of Cambridge Department of Applied Economics, Occasional Paper 9 (1967)

(12) NUPE, Public Employee (Oct. 1970)

(13) RC on Trade Unions etc., Report (1968), PP I967-8 xxxir, Cmnd 3623

(14) RC on the Press, Cmnd I8I I, PP I96 I-2 Xxi, appendix xiI, annex 8: 'Restrictive Practices'

(15) RC on Trade Unions etc., Research Paper, no. 4

(I6) Allan Flanders, 'The Fawley Blue Book. An Initiative in Labour Relations', Esso Magazine, xII, no. 3 (I963)

(17) The Times (22 Jan. 1964)

(18) DATA, The Draughtsman (March I964)

(19) Sunday Telegraph (1 March I964): 'Trade Unionists under the Law', George Doughty, General Secretary of DATA

(20) The Trade Disputes Act, I 965

(2 I) Incomes Policy: The Next Step, Cmnd i 626 (1962)

(22) T.U. C. Statement on Economic Policy and the N. E. D. C. (24 Jan. I962)

(23) National Incomes Commission, Cmnd I 844 ( I962): Terms of reference

(24) National Incomes Commission, Remuneration of Academic Staff in Universities and Colleges of Advanced Technology (1964), PP 1963-4 xvir, Cmnd 2317

(25) Court of Inquiry into the Electricity Supply Industry. Trade Unions' Statement (1964), PP г963-4 xv Cmnd 236 I 
(26) Working for Prosperity. The National Plan in Brief (1964)

(27) Joint Statement of Intent on Productivity, Prices and Incomes ( 6 Dec. 1964)

(28) Machinery of Prices and Incomes Policy, Cmnd 2577 (1965)

(29) 'Employment Incomes', Prices and Incomes Policy, Cmnd 2639 ( I965)

(30) Jack Cooper, Industrial Relations: Sweden Shows the Way, Fabian Research Series no. 235 ( 1963)

(31) TUC, Sweden-Its Unions and Industrial Relations (May 1963)

(32) CBI, Spokesman for British Industry (n.d.)

(33) NUGMW, Why An Incomes Policy? (Esher, n.d. [1964])

(34) NUGMW, Productivity, Prices and Incomes (Esher, 1966)

(35) Peter Jenkins et al., The Trades Union Congress 1965, from the Guardian (Manchester, 1965)

(36) TUC, Incomes Policy. Speech by George Woodcock, TUC General Secretary at a Conference of Executive Committees of Affliated Organisations . . . London ... March 2 ig67 ( 1967$)$

(37) TUC, Economic Review and Report of a Conference of Executive Committees of Affiliated Organisations ( 1968 )

(38) RC on Trade Unions and Employers' Associations, Report, Cmnd 3623 ( 1968$)$

(39) Ibid.

(40) Ibid.

(4I) Ibid.: 'Official, Unofficial and other Stoppages of Work due to Industrial Disputes. Average Annual Figures for Stoppages in the Period I $964-66$ '

(42) Ibid.

(43) Ibid.

(44) Ibid.: Note of Reservation by Mr Andrew Shonfield

\section{The Search for a Solution}

(1) Conservative Political Centre, Fair Deal At Work. The Conservative Approach to Modern Industrial Relations (April I968)

(2) In Place of Strife. A Policy for Industrial Relations, Cmnd 3888 (1969)

(3) Conservative Central Office, Industrial Relations Reform: The Bill in Brief! (197 I)

(4) Industrial Relations Bill, 1970: Introductory

(5) TUC, Report (197I): Speech of Victor Feather, General Secretary

(6) P. 7. O'Connor (applicant) v. Macpherson Bros (Wales) Ltd (respondents) [r974] IRLR 306

(7) G. R. Rubin, 'The Pendulum Swings Again. The Trade Union and Labour Relations Act, I974', Journal of the Law Society of Scotland (Dec. 1974) 
(8) AUEW (Engineering Section), Journal (Sept. 1974): Editorial by Hugh Scanlon

(9) Electrical, Electronic and Plumbing Trade Union, Contact (Feb. 1974): Article by Charles Lovell

(10) Financial Times (27 Nov. 1974): Closed Shops

(I I) Ron Smith, 'The Future of Employee Directors', British Steel (April I972)

(12) K. Coates and T. Topham, The New Unionism. The Case for Workers' Control (1972)

(13) Alan Fox, Industrial Sociology and Industrial Relations, RC on Trade Unions and Employers' Associations, Research Papers no. 3 ( I 966)

(14) Department of Employment Gazette (Nov. 1974): 'Membership of Trade Unions at End - I973'

(15) TUC Report 1972: Affiliated Societies

(16) Membership of trade unions I892-1972, HMSO, British Labour Statistics. Historical Abstract I886-1968 (1971); British Labour Statistics. Year Book 1975 (1977); Dept of Employment Gazette (November 1977) 